\title{
OBSERVATORIO
}

\section{RESEARCH ON POLITICAL INFORMATION AND SOCIAL MEDIA: KEY POINTS AND CHALLENGES FOR THE FUTURE}

\author{
Investigación sobre información política y redes \\ sociales: puntos clave y retos de futuro
}

\section{Andreu Casero-Ripollés}

Nota: Este artículo se puede leer en español en:

http://www.elprofesionaldelainformacion.com/contenidos/2018/sep/01_esp.pdf

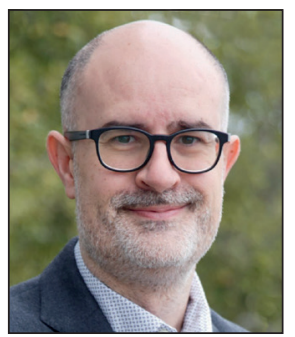

Andreu Casero-Ripollés is a professor of Journalism and dean of the Faculty of Humanities and Social Sciences at the Universitat Jaume I de Castelló (Spain). Previously, he was head of the Department of Communication Sciences and director of Journalism Studies. He holds a degree from the Universitat Autònoma de Barcelona and a PhD from the Universitat Pompeu Fabra. He is a member of the Institut d'Estudis Catalans. He has been a visiting researcher at the universities of Columbia (United States) and Westminster (UK), among others. He studies political communication and the transformation of journalism in the digital environment. He has published articles in journals such as Information, communication \& society; International journal of press/politics; Journalism; American behavioral scientist; International journal of communication; and Journalism practice. https://orcid.org/0000-0001-6986-4163

Universitat Jaume I de Castelló, Facultat de Ciències Humanes i Socials, Departament de Ciències de la Comunicació Avda. Vicent Sos Baynat, s/n. 12071 Castelló de la Plana, Spain casero@uji.es

\begin{abstract}
The key points of the transformations that social media have generated in the field of political information are identified. Social media consolidation is bringing with it a new, more hybrid communicative environment and a logic based on new principles and operating criteria that affect the entire informative process. Therefore, the impact of digital platforms on the production, distribution, and consumption of political information is examined from a critical literature review. To conclude, an approach to pending future challenges for research in this highly dynamic field is offered.
\end{abstract}

\section{Keywords}

Political information; Political communication; Social media; Journalism; Political news; Digital platforms; Digital media.

\section{Resumen}

Se identifican los puntos clave de las transformaciones que las redes sociales han generado en el ámbito de la información política. Su consolidación está trayendo consigo un nuevo entorno comunicativo más híbrido y una lógica basada en nuevos principios y criterios de funcionamiento que afectan a la totalidad del proceso informativo. Por ello, se examina el impacto de las plataformas digitales en la producción, distribución y consumo de información política a partir de una revisión en profundidad de las investigaciones previas. Para finalizar, se ofrece una aproximación a los retos pendientes de futuro para la investigación en este campo altamente dinámico.

\section{Palabras clave}

Información política; Comunicación política; Redes sociales; Periodismo; Noticias políticas; Plataformas digitales; Medios digitales.

Casero-Ripollés, Andreu (2018). "Research on political information and social media: Key points and challenges for the future". El profesional de la información, v. 27, n. 5, pp. 964-974. 


\section{Introduction}

Social media have caused a great wave of changes in society and also in politics; a wave that has left in its wake a lot of research about the impact social media have had on political information. The objective of this article is to present a comprehensive panorama of the main transformations that social media have introduced in the production, distribution, and consumption of political information. At this end, an in-depth review of the previous literature was carried out, and the most significant findings are highlighted. Likewise, we also offer an approach to the pending challenges for research in this field that is characterized by its dynamism.

The consolidation of social media in political communication has placed technology at the center of academic debate. Although this is not the only factor behind the transformation of this field, its protagonism is inescapable.

The architecture and technical characteristics of social media open and close possibilities of reconfiguration of the processes of production, circulation, and consumption of political information. They create or spoil opportunities for the redistribution of power in the communicative scenario.

Digital platforms are changing political information, but they are not replacing journalism and conventional media. This produces a new hybrid environment in which the two logics, the one linked to digital media, on the one hand, and the one associated with the mainstream media system, on the other, sometimes coexist harmoniously, generating cooperation and synergies, and on other occasions collide, causing conflicts and tensions (Chadwick, 2017). In any case, both overlap and interrelate constantly.

\section{Two logics, that of digital media and that} of the mainstream media system overlap and interrelate constantly

The new logic of network media (Klinger; Svensson, 2016; Van-Dijck; Poell, 2013) orbits around concepts such as self-production, user-generated content, social connectivity, virality, incidental consumption, affective audiences, and datafication. Its introduction into the communication system is causing changes in the information cycle and in the role of journalism (Enli, 2017). Currently, media professionals are not the only ones managing that process, and the production and distribution of political information involves more actors and more media and platforms. Ordinary users, who are not part of the political or communicative elites, can intervene more actively and influence the information dynamics. In addition, a wide variety of media (blogs, social networks, instant messaging services, collaborative video portals, digital newspapers, etc.) contribute, together with television, radio and the press, to shape the information field. The boundaries between media tend to be diluted, enhancing interdependencies. Taken together, this new scenario provides a more fluid structure of opportunities (Casero-Ripollés, 2015). Therefore, Chadwick (2017) raises the need to replace the traditional concept of news cycle with political information cycle. Inside this cycle, production, di- ffusion, and consumption are subject to various changing processes, which are analyzed in the following sections.

The borders between the media tend to be diluted, enhancing interdependencies

\section{Transformations in production}

Social media expand the number and type of actors that interact and negotiate in the field of political communication. From a scenario marked, almost exclusively, by the relations between journalists and politicians, we are moving to a more open and decentralized panorama in which a greater number of actors participate in the exchanges that contribute to define the public sphere, thanks to digital platforms. This decisively affects the production of political information. Any user can develop content autonomously. Thus, professionally created information coexists with content generated by users in an amateur way (Van Dijck, 2009; Flichy, 2010). In a century we have gone from a scenario marked by scarcity to one characterized by informative abundance, and even overload (Keane, 2013).

Abundance has great potential since it facilitates citizens to get information on political issues. It can even be an ally of the democratic project since it enables transparency and accountability on the centers of power, although, for this, it is necessary to activate processes of political monitoring (Keane, 2009). Social media allow citizens to promote and carry out these processes of scrutiny and public control over the power (Feenstra; Casero-Ripollés, 2014).

However, the abundance of information also generates instabilities, conflicts, and contradictions in the political scenario. Greater quantity is not necessarily equal to higher quality. This poses numerous challenges such as filtering, attributing relevance, and contextualizing political information. A key aspect connected to this has to do with the extension and facilitation of misinformation. The strong decentralization in the production and distribution of information provided by social media, together with the anonymity that favors the digital environment (difficulty of knowing who is behind the content), are factors that bring on this phenomenon. This means the emergence of fake news that, as has been shown in Brexit and in the victory of Donald Trump, can have important effects on the political and electoral dynamics and generate serious democratic consequences (Bennett; Livingston, 2018).

\section{The information created professionally coexists with the one generated by users in an amateur way}

Social media production facilities have caused the content circulating through them to be manipulated to assemble, add, or remove information (Manovich, 2001). This opens the way to re-framing processes, reallocating meaning, or recontextualizing information that can alter its meaning. The creation of satirical memes by thousands of users from 
statements by a politician or aspects of current events, such as elections or a motion of censure, have become a common practice (Meso-Ayerdi; Mendiguren-Galdospín; Pérez-Dasilva, 2017). This connects with the growth experienced in the digital environment by infotainment. On the one hand, the networks allow new intimate personalization strategies that show the intimacies of the life of politicians with the will to humanize their figure and achieve the support and attention of citizens through "likes" and followers (Kruikemeier et al., 2013). On the other, they allow the emergence of new communicative practices based on spectacularization or infosatire. A good example of this was the participation of Esquerra Republicana's Congress deputy Gabriel Rufián, who submitted himself for two hours to questions on any topic of the users' choice on the controversial ForoCoches website in January 2017.

\section{Social media allow the emergence of new communicative practices based on spectacularization or infosatire}

The production of political information in social media can also affect the process of setting the public agenda. Both political and social actors use these digital platforms to promote their issues and demands and try to place them at the center of public debate. In this sense, previous research has identified strategies such as the reversed agenda-setting (Sung-Tae; Young-hwan, 2007; Casero-Ripollés, 2015), which in Spain has been highlighted in the a case of the Plataforma de afectados por la hipoteca (Platform of people affected by mortgages) (Alonso-Muñoz; Casero-Ripollés, 2016), or the two-way street mediatization of politics, such as the one carried out by Podemos, which gives politicians the ability to condition the media agenda (Casero-Ripollés; Feenstra; Tormey, 2016). In both cases, the digital front is an indispensable element, although not exclusive, for the implementation of this type of dynamics.

Not all citizens benefit equally from these possibilities when it comes to producing content (Hargittai; Hsieh, 2013). The education level and the frequency of use of these platfor$\mathrm{ms}$ are factors that condition the creation of political information in the digital environment (Casero-Ripollés, 2017). This generates digital inequalities that have real democratic costs.

Previous research shows that the main use that political actors give to social media is the dissemination of information, especially of their own production, taking advantage of the self-production advantages offered by digital platforms (Marcos-García; López-Meri; Casero-Ripollés, 2017). This implies that the interactive possibilities are relegated to the background (Miquel-Segarra; Alonso-Muñoz; Marcos-García, 2017). Politicians preeminently seek to connect with citizens directly by resorting to self-presentation and self-expression. In this framework, the construction of its image has gained a new impetus. Social media allow emotional connection with users and generate authenticity around a political leader, so that he is perceived as reliable, genuine, and close (Enli, 2015). To this objective is oriented a large

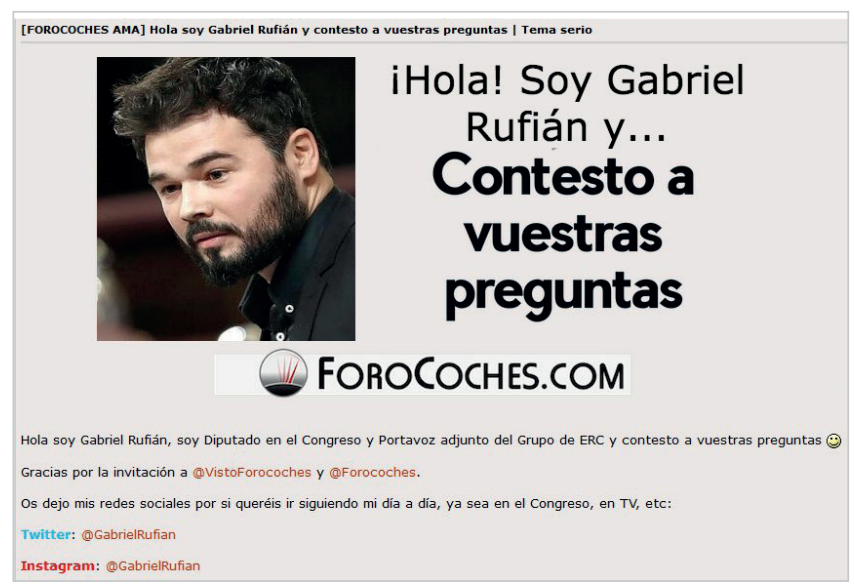

https://www.forocoches.com/foro/showthread.php?t=5393332

part of the content production of politicians. More than offering information by itself, the main purpose is self-promotion. The use of Instagram is revealing in this sense (Selva-Ruiz; Caro-Castaño, 2017).

One of the main promises that accompanied the arrival of social media was their potential to establish interactions between the actors of political communication, enabling the establishment of a dialogue between them (Ward; Gibson; Lusoli, 2003). This faculty was attributed positive effects on democracy as the reduction of disaffection or the rapprochement between rulers and the governed. However, the use given to these platforms shows that both politicians and journalists underutilize their dialogic potential (Domingo, 2008; Jackson; Lilleker, 2009; Koc-Michalska et al., 2016; Magin et al., 2017; Larsson, 2017). They hardly encourage conversation with users and rarely interact with them, responding to their questions or comments online, although citizens see digital platforms as an adequate space to express their opinion (Guallar et al., 2016). The dynamics of controlled interactivity have been imposed (Stromer-Galley, 2014), in which, in order to avoid losing control over the communicative process, the interaction is ignored or minimized, and the dissemination of information prevails. As a result, production assumes a strong role.

\section{The main use that political actors give to social media is the dissemination of information, especially of their own pro- duction}

\section{Novelties in the distribution}

The digital environment introduces notable novelties in the distribution of political information. The main one has to do with the multiplication of the platforms through which content circulates. We have gone from a scenario in which the dissemination of information was carried out through television, radio, and the press, to another where it is more decentralized. This has meant a loss of control over the flow of information by journalists who are no longer the only ones acting as gatekeepers. Now any user can access digital channels to circulate their messages. This circumstance increases 
the ease of the dissemination of information. Social media have introduced self-distribution (Castells, 2009), in which the users themselves decide through which channels they initiate dissemination of a content.

\section{Journalists are no longer the only ones acting as information gatekeepers}

The result is a media environment much more dense, saturated, and complex, in which legacy media coexists with a growing multiplicity of digital platforms, such as Facebook, Twitter, Instagram, WhatsApp, or YouTube, among others. This entails a high communicative fluency, the fragmentation of the audience, and the increase of the choice possibilities (Van-Aelst et al., 2017), being able to even generate a balkanization of the public sphere (Sunstein, 2009).

The incorporation of the users into the distribution, together with the architecture of the social media, has caused changes in the circulation of political information in the digital environment. In this context, three forms of filtering coexist that condition the diffusion of content (Boczkowski; Mitchelstein; Matassi, 2018):

1) The first is the editorial selection, exercised by journalists and media.

2) The second is of a technical filtering, launched by the owners of the platforms, and is linked to the algorithms that determine which information is most visible to users (Bucher, 2012; Gillespie, 2014; Bossetta, 2018).

3) The third is the social filtering, associated with the connectivity that digital media propitiates (Van-Dijck, 2013). As a result of this, our network of contacts and friendships conditions, in part, the information we receive through digital platforms.

A new form of circulation of political information emerged: virality

Linked to this triple filtering process, especially algorithms and the exchange based on social connectivity, a new form of circulation of political information emerged: virality. This property, which implies a rapid and massive distribution of content through digital platforms thanks to the exchange between users, constitutes one of the ideal characteristics of the logic of networked media (Klinger; Svensson, 2016). In addition, it is a differential element with respect to the logic of legacy media. Re-tweeting a message, sharing content, or clicking on the "like" button, users contribute to expanding the circulation of content and attributing relevance to others. The public, together with the algorithms, has a key role in the distribution, which assumes a more horizontal model. Capturing and mobilizing the attention of the audience means generating more attention on this type of content. Virality is based on the principle of popularity and is associated with the attention economy (Fuchs, 2017), since its activation ensures a broad audience and a high potential for attention. This new mechanism of circulation of information, typical of the digital environment, coexists with the vertical diffusion

\begin{tabular}{|l|l|}
\hline \multicolumn{1}{|c|}{ Social network } & \multicolumn{1}{c|}{ More appropriate for } \\
\hline Twitter & Dissemination of news \\
\hline Facebook & $\begin{array}{l}\text { Creation of user communities, and network } \\
\text { organization and mobilization }\end{array}$ \\
\hline WhatsApp & Exchange of personal information \\
\hline YouTube & $\begin{array}{l}\text { Photographic and audiovisual content, with a } \\
\text { special focus on entertainment }\end{array}$ \\
\hline Instagram & Photographic and audiovisual content \\
\hline
\end{tabular}

practiced by legacy media. Despite this, the latter no longer has a monopoly over what circulates and what does not in the political sphere (López-García, 2017), something that has important repercussions on the political content that reaches the audience.

The public, together with the algorithms, has a key role in the distribution, which assumes a more horizontal model

Another element that influences distribution is the technical configuration of social media. The architecture of each digital platform is different (Nahon, 2016) and, therefore, each one has its own differential characteristics (Bossetta, 2018). This fact affects, notably, the circulation of content. So, for example, previous research highlights that Twitter is more appropriate for the dissemination of news and current content while Facebook is more oriented towards the creation of user communities and, therefore, to organization and mobilization (Stier et al., 2018). WhatsApp, on the other hand, is directed towards the exchange of personal information and YouTube and Instagram are associated with the dissemination of photographic and audiovisual content, with a special focus on entertainment in the first one. Therefore, although political information can circulate on any platform, its distribution parameters can differ significantly depending on the characteristics of the channel, conditioning its dissemination.

\section{Changes in consumption}

The transformation in the production and distribution of political information operated by social media has placed us in a high-choice media environment (Van-Aelst et al., 2017). Citizens have a lot to choose between and traditional sources (press, radio, and television) are losing their place of primacy that existed before the thrust of digital platforms, which are becoming primary sources for information and news. In 2018, 36\% of news consumers in 37 countries used Facebook primarily to inform themselves (Newman et al., 2018). A figure that reached $48 \%$ in the case of Spain.

This circumstance is generating the appearance of new forms of behavior within the public when consuming political information. In the first place, access to this type of content is brief and uninterrupted and occurs at any time and any place --thanks, among other devices, to smartphones (Boczkowski; Mitchelstein; Matassi, 2018). In this way, an 
endless cycle is created in information consumption where the periodicity has been definitively overcome. In addition, it is becoming more individualized. Long gone is the time when families gathered in front of television to receive the news (Wolton, 2005). Now, each user accesses it individuaIly and customized (Solito; Sorrentino, 2018). For example, over the last three years, there has been a strong growth in the number of users who receive information alerts through their mobile phones, already standing at a global level of $16 \%$ (Newman et al., 2018). Social media also favor the emergence of affective audiences. It is a dynamic process of structuring network users that are mobilized and connected or disconnected, through expressions of feelings (Papacharissi, 2015). Isolated individuals are articulated around affective appeals, with which, political information capable of generating emotions, both positive or negative, can mobilize large numbers of people to their consumption.

A key practice that the digital environment has imposed on access to political information is the rise (and growing extension) of incidental consumption (Fletcher; Nielsen, 2018). Social media allow a casual discovery of news that causes users, who have not been actively searching, to be exposed to the news. According to the Reuters Institute digital news report 2018, slightly more than half of respondents (53\%) in 37 countries, especially young people and those less interested in the news, accidentally discover news online as a regular way of staying informed (Newman et al., 2018).

\section{Access to political information is brief and uninterrupted, and occurs at any time and any place}

This contrasts with the traditional model, linked to press, radio, and television, in which the public intentionally and deliberately searched for information proactively in an environment where information was a scarce commodity. Social media have introduced the belief that news, in a context of informative abundance, seeks users, who should not have to do anything special to receive the information. It is about the perception "the news finds me" (Gil-de-Zúñiga; Weeks; Ardèvol-Abreu, 2017). According to it, individuals believe they are well informed without actively following the news. They also believe that important information ends up finding them sooner or later, thanks to digital platforms such as Facebook or Twitter. A recent study has shown that those who display this information behavior use fewer sources linked to legacy media and have less political knowledge (Gil-de-Zúñiga; Weeks; Ardèvol-Abreu, 2017). Another effect is the increase in political polarization and the ideological radicalization of the audience (Van-Aelst et al., 2017).

A second practice of information consumption that has been imposed in the digital environment is the perception that "the information is out there" (Toff; Nielsen, 2018). Whomever believes this thinks that any information is available and that it will be easy to find thanks, especially, to search engines like Google. This suggests that information is ubiquitous and is, at all times, around us within the reach of a click, generating a new information ambient (Hermida, 2010).
A key practice that the digital environ- ment has imposed on access to political information is incidental consumption

The digital environment also opens up significant challenges for the consumption of political information. One of the main ones has to do with the use of big data or datafication. This formula supposes the quantification of user activities in social media (Mayer-Schönberger; Cukier, 2013), assuming that whatever citizens do in digital platforms leaves traces (Jungherr, 2015). These can be collected for multiple purposes: market research, offer customized advertising, activate digital surveillance, mobilizing and persuading citizens by sending them, through their social media, personalized information according to their interests and ideology (Kreiss, 2016). In this way, the communicative strategy put in place by a political party or actor can be adjusted more precisely to its potential audience. For this, three steps are used:

1) the identification or location of the public that responds to the profile sought, by combining various types of data;

2) sending personalized messages to those users; and, finally,

3) analysis, even in real time, of the impact of these messages that serves to draw conclusions about the result to guide future strategies (Bossetta, 2018).

This practice, on the rise in political communication, involves ethical and political issues related to individual freedom, the unauthorized use of data, or privacy (Bakardjieva; Gehl, 2017), as the case of Cambridge Analytica has recently revealed (Ward, 2018).

Finally, several studies have explored the relationships between the consumption of information in social media and

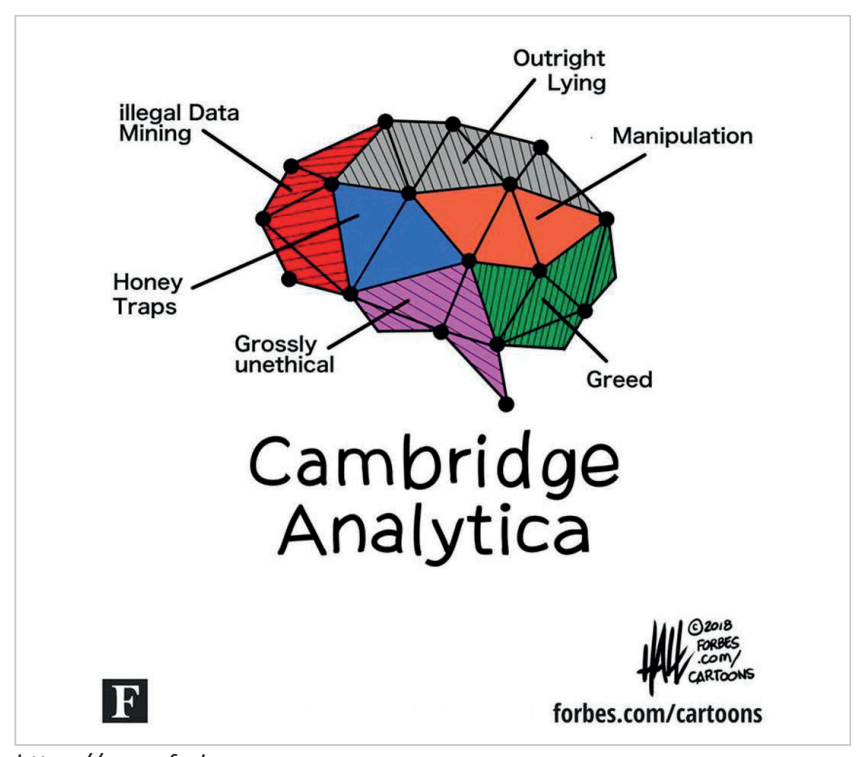

https://www.forbes.com 
the political participation of citizens. In general, those investigations that measure the political use of these digital platforms find tangible effects both in online and offline participation (Gil-de-Zúñiga; Jung; Valenzuela, 2012). However, these effects, despite being positive, are modest (Boulianne, 2015).

Individuals believe they are well informed without actively following the news. They also believe that important information ends up finding them sooner or later

\section{Looking forward: pending challenges for the future of research}

After analyzing the impact of social media on the production, distribution, and consumption of political information, in this section we will examine critically the pending challenges for research in this field. Here we define nine key points that constitute challenges, the resolution of which may favor the progress of research on this topic:

1. Predominance of studies focused on a single country;

2. Role of research focused on a single platform.

3. Preference for campaigns' electoral processes.

4. Priority towards platforms based on the one-to-many communication model as opposed to the one-to-one.

5. Analysis of political influence in the digital environment.

6. Study of changes in the professional profiles of political communication.

7. Need to introduce the critical vision.

8. Impulse of methodological creativity, and

9. Propitiate the advance of theory in this field.

In the first place, previous research on political information and social media has been based, as a priority, on studies focused on a single country. In this context, the work focused on the United States has been predominant, mainly due to the impact of digital platforms in that country and its potential to transform political communication, especially since the campaign carried out by Barack Obama in 2008 that introduced notable novelties on the digital front (Bimber, 2014; Stromer-Galley, 2014). However, it has been shown that the context in which the use of social media occurs is determinant and conditions the results (Dimitrova; Matthes, 2018; Boulianne, 2017). The idiosyncratic characteristics of the political system with its legal determinants and its party system, the media system, the penetration of digital technologies, the political culture of citizenship and the organization of electoral campaigns have a decisive impact on how social media are used (Van-Aelts et al., 2017). This makes it difficult to generalize the results globally. Therefore, one of the pending challenges is the need to promote comparative studies between countries (Boulianne, 2015). Only then can we know more about the factors that affect the use and effects of social media in the political sphere.

Another feature of previous research has to do with the prominence of studies focused on a single platform. Most of the previous work has been concentrated in a single network, with a predominance of Twitter (Weller et al., 2014; Campos-Domínguez, 2017; Jungherr, 2016). This generates a paradox: despite the fact that the largest volume of users is on Facebook, the research is done on Twitter. The reasons that explain this circumstance are diverse. From the greater accessibility of the data offered by this microblogging network, and that facilitates the research task, to its marked orientation towards news and the dissemination of information, which connect it more with politics, through the high presence of the politics and journalism elites on Twitter that make it the nerve center of political influence compared to other platforms. In fact, journalists consider it as a as a way to infer public opinion (Dubois; Gruzd; Jacobson, 2018), especially thanks to trending topics.

\section{Despite the fact that the largest volume of users is on Facebook, the research is done on Twitter}

This dependence on Twitter generates several potential dangers:

1) The first is to lose sight of the innovation that other platforms introduce in political communication.

2) The second is to try to infer the findings of a platform to the set of social media, understood as a whole. The latter collides with the fact that each platform has different characteristics, derived from its digital architecture (Bossetta, 2018), which cause it to be used for different purposes and generate different dynamics and effects (Stier et al., 2018). More studies are needed to analyze comparatively multiple social media and, also, to propose cross-media approaches that examine the intersections between digital platforms and legacy media. Thus, we can know more precisely their contribution to the transformation of political communication.

\section{Twitter has become the nerve center of political influence}

3) A third characteristic is the predominance of investigations related to electoral campaigns (Jungherr, 2016). Most studies focus on analyzing the use of social media during elections (Bruns et al., 2016; Coleman; Freelon, 2015; Dader; Campos-Domínguez, 2017; López-García; Valera-Ordaz, 2017). This generates that the theories are anchored in specific cases and have a limited scope (Karpf, 2017). Research is needed to broaden the focus of attention to more varied objects of study, linked, mainly, with those phenomena that are contributing to change political communication from the digital environment.

Another trend is the pre-eminence of research on platforms based on the one-to-many communication model, such as Twitter, Facebook, or Instagram. In contrast, the study of the incidence of one-to-one platforms, such as WhatsApp or Telegram, in political communication remains practically 
unexplored. The pending challenge is to promote research on these networks that are acquiring increasing relevance to obtain and exchange political information and that have a high social impact. In 2018, WhatsApp had 25 million users in Spain (IAB Spain, 2018) and 1,500 million worldwide (Constine, 2018), data that show the need to extend the research to these networks one-to-one to analyze their impact on politics.

The incidence of one-to-one platforms, such as WhatsApp or Telegram, in political communication remains practically unexplored

Social media configure an environment open to a multiplicity of actors that interact with each other. New actors emerge, in many cases detached from the political and communicative elites, capable of influencing the cycle of political information, such as activists or social movements (Jost et al., 2018; Sampedro; Martínez-Avidad, 2018; Casero-RipoIlés, 2015). In this context, political influence is being reconfigured in social media. One of the challenges for research is to know how this process is articulated. The questions to answer are diverse. What rules and dynamics linked to the logic of networked media and the characteristics of digital platforms affect political influence? What actors and strategies are capable of influencing more in the construction of the agenda and the public debate?

The consolidation of social media is affecting the role of all actors in political communication. Political consultants must develop new strategies and skills for the efficient communicative management of social media (Kreiss; Lawrence; McGregor, 2018; Solito; Sorrentino, 2018). At the same time, political journalists are obliged to incorporate new techniques in the production and distribution of information, on the one hand, and in the management of their relationship with the audience, on the other. The use of web analytics, SEO or the creation of the personal brand are some of these new elements (Justel-Vázquez; Micó-Sanz; Sánchez-Marín, 2016). Even the digital environment is propitiating the proliferation of new actors that go beyond the borders and the traditional subjects of the field. Among these are the new digital opinion leaders or influencers, who are able to accumulate a high symbolic capital that allows them to effectively influence the information flow. The study of both the changes in the professional profiles of the classical actors of political communication and the emergence of new ones is still unattended.

It is also a pending challenge to introduce with more force and incidence the critical vision in the studies on political information and social media. Frequently, it is forgotten that the use of these platforms generates democratic and social consequences. The relevance of the research and its social contribution will increase if it is able to determine the effects of the digital environment both for our political system and for our daily life. Examining how they affect established power relations and existing social hierarchies is an essential objective (Castells, 2009), as well as introducing a perspective focused on the generation of digital inequalities that the new technological environment fosters (Casero-Ripollés, 2017). Knowing which actors and voices manage to empower themselves and who are not capable, and why, currently acquire a high value (Bakardjieva; Gehl, 2017). Incorporating a critical vision implies opening the research agenda to issues that go beyond the uses given to networks and that connect in their political dimension. This has to do with the fact that its technological configuration generates political implications that make up ways to exercise power, conditioning, for example, what type of information users receive and what content they gain greater visibility ( $\mathrm{Na}$ hon, 2016).

Social networks are not neutral artifacts, but are political and social spaces with strong democratic implications. Its digital architecture is integrated by technical protocols that allow, constrict and influence the behavior of users, generating one or other communicative practices (Bossetta, 2018). The structure of the network, its functionality, the configuration of the algorithms and the use of big data are key factors that affect the production, circulation and consumption of information in digital platforms (Bucher, 2012; Gillespie, 2014; Bossetta, 2018). These components decisively influence the visibility and selection of the contents. By controlling this technical dimension, certain actors have hegemony over others, conditioning their values and behavior in the digital environment (Nahon, 2016). The analysis of these issues should also be addressed.

\section{Frequently, it is forgotten that the use of these platforms generates democratic and social consequences}

Finally, research on political information and social media faces a considerable methodological and theoretical challenge. The answers to how to measure the use, content and effects of social platforms on politics have not reached conclusive answers yet (Dimitrova; Matthes, 2018). The recourse to a high diversity and methodological heterogeneity without losing the scientific rigor together with the methodological innovation will be key for this field to advance. The digital environment, thanks to its technological component, allows great creativity in the field of methodology, enabling researchers to apply original and novel formulas (Karpf, 2012; Jungherr, 2015). Something that gives value to the methodological design and gives it new possibilities. The stimulation of this methodological thinking opens an attractive challenge. In this framework, in addition, the integration of big data generates new and interesting perspectives. Its protagonism introduces the developments and tools of computer science in communicative and social research, posing many challenges for social scientists (Jungherr; Theocharis, 2017).

Regarding the theoretical front, research in this field has the challenge of developing and building strong theoretical models that contribute to improving knowledge on the subject (Dimitrova; Matthes, 2018; Karpf, 2017). Studies should not only describe, but explain and interpret to help understand 
how and why social media are used in politics and what social and democratic effects and transformations they drive. It is not just about knowing what happens, but how, why and with what effects. Moving the theory forward, beyond isolated cases, is a challenge of a great magnitude that it is urgent that researchers face. Only, this way, will this field be able to settle and reach the relevance it deserves, taking advantage of the big wave.

Social media are not neutral artifacts, but are political and social spaces with strong democratic implications

\section{Support}

This article is part of the research project CSO2017-88620-P, funded by the Ministry of Economy and Competitiveness of the Spanish Government within the State Plan for Scientific and Technical Research and Innovation 2013-2016.

\section{References}

Alonso-Muñoz, Laura; Casero-Ripollés, Andreu (2016). “La influencia del discurso sobre cambio social en la agenda de los medios. El caso de la Plataforma de Afectados por la $\mathrm{Hi}-$ poteca". Obets. Revista de ciencias sociales, v. 11, n. 1., pp. 25-51.

https://doi.org/10.14198/OBETS2016.11.1.02

Bakardjieva, Maria; Gehl, Robert W. (2017). "Critical approaches to communication technology - the past five years". Annals of the International Communication Association, v. 41, n. 3-4, pp. 213-219.

https://doi.org/10.1080/23808985.2017.1374201

Bennett, W. Lance; Livingston, Steven (2018). "The disinformation order: Disruptive communication and the decline of democratic institutions". European journal of communication, v. 33, n. 2, pp. 122-139.

https://doi.org/10.1177/0267323118760317

Bimber, Bruce (2014). "Digital media in the Obama campaigns of 2008 and 2012: Adaptation to the personalized political communication environment". Journal of information technology \& politics, v. 11, n. 2, pp. 130-150.

https://doi.org/10.1080/19331681.2014.895691

Boczkowski, Pablo J.; Mitchelstein, Eugenia; Matassi, Mora (2018). "'News comes across when I'm in a moment of leisure': Understanding the practices of incidental news consumption on social media". New media \& society. https://doi.org/10.1177/1461444817750396

Bossetta, Michael (2018). "The digital architectures of social media: Comparing political campaigning on Facebook, Twitter, Instagram, and Snapchat in the 2016 US election". Journalism \& mass communication quarterly, v. 95, n. 2, pp. 471-496. https://doi.org/10.1177/1077699018763307

Boulianne, Shelley (2015). "Social media use and participation: A meta-analysis of current research". Information, communication \& society, v. 18, n. 5, pp. 524-538. https://doi.org/10.1080/1369118X.2015.1008542
Boulianne, Shelley (2017). "Revolution in the making? Social media effects across the globe". Information, communication \& society, 1-16.

https://doi.org/10.1080/1369118X.2017.1353641

Bruns, Axel; Enli, Gunn; Skogerbö, Eli; Larsson, Anders; Christensen, Christian (eds.) (2016). Routledge companion to social media and politics. New York: Routledge. ISBN: 978 $113886076 \mathrm{X}$

Bucher, Taina (2012). "Want to be on the top? Algorithmic power and the threat of invisibility on Facebook". New media \& society, v. 14, n. 7, pp.1164-1180.

https://doi.org/10.1177/1461444812440159

Campos-Domínguez, Eva (2017). "Twitter y la comunicación política". El profesional de la información, v. 26, n. 5, pp. 785-793.

https://doi.org/10.3145/epi.2017.sep.01

Casero-Ripollés, Andreu (2015). “Estrategias y prácticas comunicativas del activismo político en las redes sociales en España". Historia y comunicación social, v. 20, n. 2, pp. 245260.

https://doi.org/10.5209/rev_HICS.2015.v20.n2.51399

Casero-Ripollés, Andreu (2017). “Producing political content for web 2.0: Empowering citizens and vulnerable populations". El profesional de la información, v. 26, n. 1, pp. 13-19.

https://doi.org/10.3145/epi.2017.ene.02

Casero-Ripollés, Andreu; Feenstra, Ramón A.; Tormey, Simon (2016). "Old and new media logics in an electoral campaign: The case of Podemos and the two-way street mediatization of politics". The international journal of press/ politics, v. 21, n. 3, pp. 378-397.

https://doi.org/10.1177\%2F1940161216645340

Castells, Manuel (2009). Comunicación y poder. Barcelona: Editorial UOC. ISBN: 9788420684994

Chadwick, Andrew (2017). The hybrid media system: Politics and power. New York: Oxford University Press. 2a ed. ISBN: 9780190696733

Coleman, Stephen; Freelon, Deen (eds.). (2015). Handbook of digital politics. Cheltenham: Edward Elgar Publishing. ISBN: 9781782548751

Constine, Josh (2018). "WhatsApp hits 1.5 billion monthly users. \$19B? Not so bad". Techcrunch, January $31^{\text {st }} 2018$.

https://techcrunch.com/2018/01/31/whatsapp-hits-1-5billion-monthly-users-19b-not-so-bad

Dader, José-Luis; Campos-Domínguez, Eva (eds.) (2017). La búsqueda digital del voto. Cibercampañas electorales 201516. Valencia: Tirant lo Blanch. ISBN: 9788491691846

Dimitrova, Daniela V.; Matthes, Jörg (2018). "Social media in political campaigning around the world: Theoretical and methodological challenges". Journalism \& mass communication quarterly, v. 95, n. 2, pp. 333-342. https://doi.org/10.1177/1077699018770437

Domingo, David (2008). "Interactivity in the daily routines of online newsrooms: Dealing with an uncomfortable 
myth". Journal of computer-mediated communication, v. 13, n. 3, pp. 680-704.

https://doi.org/10.1111/j.1083-6101.2008.00415.x

Dubois, Elizabeth; Gruzd, Anatoly; Jacobson, Jenna (2018). "Journalists' use of social media to infer public opinion: The citizens' perspective". Social science computer review. Online first.

https://doi.org/10.1177/0894439318791527

Enli, Gunn (2015). Mediated authenticity. How the media constructs reality. New York: Peter Lang. ISBN: 9781 433114854

Enli, Gunn (2017). "New media and politics". Annals of the International Communication Association, v. 41, n. 3-4, pp. 220-227.

https://doi.org/10.1080/23808985.2017.1392251

Feenstra, Ramón A.; Casero-Ripollés, Andreu (2014). "Democracy in the digital communication environment: A typology proposal of political monitoring processes". International journal of communication, v. 8, pp. 2448-2468.

http://ijoc.org/index.php/ijoc/article/download/2815/1225

Fletcher, Richard; Nielsen, Rasmus-Kleis (2018). “Are people incidentally exposed to news on social media? A comparative analysis". New media \& society, v. 20, n. 7, pp. 2450 2468.

https://doi.org/10.1177/1461444817724170

Flichy, Patrice (2010). Le sacre de l'amateur. Sociologie des passions ordinaires à l'ère numérique. Paris: Le Seuil. ISBN: 9782021031447

Fuchs, Christian (2017). Social media: A critical introduction. London: Sage. ISBN: 9781473966833

Gil-de-Zúñiga, Homero; Jung, Nakwon; Valenzuela, Sebastián (2012). "Social media use for news and individuals' social capital, civic engagement and political participation". Journal of computer-mediated communication, v. 17, n. 3, pp. 319-336.

https://doi.org/10.1111/j.1083-6101.2012.01574.x

Gil-de-Zúñiga, Homero; Weeks, Brian; Ardèvol-Abreu, Alberto (2017). "Effects of the news-finds-me perception in communication: Social media use implications for news seeking and learning about politics". Journal of computer-mediated communication, v. 22, n. 3, pp. 105-123.

https://doi.org/10.1111/jcc4.12185

Gillespie, Tarleton (2014). "The relevance of algorithms". In: Gillespie, Tarleton; Boczkowski, Pablo; Foot, Kirsten (eds). Media technologies: essays on communication, materiality, and society. Cambridge: MIT Press, pp. 167-194. ISBN: 978 0262525374

Guallar, Javier; Suau, Jaume; Ruiz-Caballero, Carlos; Sáez, Albert; Masip, Pere (2016). "Re-dissemination of news and public debate on social networks". El profesional de la información, v. 25, n. 3, pp. 358-366.

https://doi.org/10.3145/epi.2016.may.05

Hargittai, Eszter; Hsieh, Yuli-Patrick (2013). “Digital inequality". In: Dutton, William H. (ed.). The Oxford handbook of internet studies. Oxford: Oxford University Press, pp. 129-

\section{ISBN: 9780199589074}

Hermida, Alfred (2010). "Twittering the news: The emergence of ambient journalism". Journalism practice, v. 4, n. 3, pp. 297-308.

https://doi.org/10.1080/17512781003640703

IAB Spain (2018). Estudio anual de redes sociales 2018. https://iabspain.es/wp-content/uploads/estudio-redessociales-2018_vreducida.pdf

Jackson, Nigel A.; Lilleker, Darren G. (2009). "Building an architecture of participation? Political parties and web 2.0 in Britain". Journal of information technology \& politics, v. 6, n. 3-4, pp. 232-250.

https://doi.org/10.1080/19331680903028438

Jost, John T.; Barberá, Pablo; Bonneau, Richard; Langer, Melanie; Metzger, Megan; Nagler, Jonathan; Sterling, Joanna; Tucker, Joshua A. (2018). "How social media facilitates political protest: Information, motivation, and social networks". Political psychology, v. 39, pp. 85-118. https://doi.org/10.1111/pops.12478

Jungherr, Andreas (2015). Analyzing political communication with digital trace data. Cham: Springer. ISBN: 9783319 203188

Jungherr, Andreas (2016). "Twitter use in election campaigns: A systematic literature review". Journal of information technology \& politics, v. 13, n. 1, pp. 72-91.

https://doi.org/10.1080/19331681.2015.1132401

Jungherr, Andreas; Theocharis, Yannis (2017). "The empiricist's challenge: Asking meaningful questions in political science in the age of big data". Journal of information, technology and politics, v. 14, n.2, pp. 97-109.

https://doi.org/10.1080/19331681.2017.1312187

Justel-Vázquez, Santiago; Micó-Sanz, Josep-Lluís; SánchezMarín, Guillem (2016). "Media and public interest in the era of web analytics: A case study of two Spanish leading newspapers". El profesional de la información, v. 25, n. 6, pp. 859-868.

https://doi.org/10.3145/epi.2016.nov.03

Karpf, Dave (2012). "Social science research methods in internet time". Information, communication \& society, v. 15, n. 5, pp. 639-661.

https://doi.org/10.1080/1369118X.2012.665468

Karpf, Dave (2017). “Digital politics after Trump”. Annals of the International Communication Association, v. 41, n. 2, pp. 198-207.

https://doi.org/10.1080/23808985.2017.1316675

Keane, John (2009). The life and death of democracy. London: Simon and Schuster. ISBN: 9780393058352

Keane, John (2013). Democracy and media decadence. Cambridge: Cambridge University Press. ISBN: 9781107614574

Klinger, Ulrike; Svensson, Jakob (2016). “Network media logic". In: Bruns, Axel; Enli, Gunn; Skogerbö, Eli; Larsson, Anders; Christensen, Christian (eds.). Routledge companion to social media and politics. New York: Routledge, pp. 23-38. ISBN: $978113886076 \mathrm{X}$ 
Koc-Michalska, Karolina; Lilleker, Darren G.; Smith, Alison; Weissmann, Daniel (2016). "The normalization of online campaigning in the web. 2.0 era". European journal of communication, v. 31, n. 3, pp. 331-350.

https://doi.org/10.1177/0267323116647236

Kreiss, Daniel (2016). Prototype politics: Technology-intensive campaigning and the data of democracy. New York: Oxford University Press. ISBN: 9780199350254

Kreiss, Daniel; Lawrence, Regina G.; McGregor, Shannon C. (2018). "In their own words: Political practitioner accounts of candidates, audiences, affordances, genres, and timing in strategic social media use". Political communication, v. 35, n. 1, pp. 8-31.

https://doi.org/10.1080/10584609.2017.1334727

Kruikemeier, Sanne; Van-Noort, Guda; Vliegenthart, Rens; De-Vreese, Claes H. (2013). "Getting closer: The effects of personalized and interactive online political communication". European journal of communication, v. 28, n. 1, pp. 53-66.

https://doi.org/10.1177/0267323112464837

Larsson, Anders O. (2017). "The news user on social media: A comparative study of interacting with media organizations on Facebook and Instagram". Journalism studies, 1-18. https://doi.org/10.1080/1461670X.2017.1332957

López-García, Guillermo (2017). "Comunicación política y discursos sobre el poder". El profesional de la información, v. 26, n. 4, pp. 573-578.

https://doi.org/10.3145/epi.2017.jul.01

López-García, Guillermo; Valera-Ordaz, Lidia (eds.) (2017). Pantallas electorales. Barcelona: Editorial UOC. ISBN: 97884 91167051

Magin, Melanie; Podschuweit, Nicole; Haßler, Jörg; Russmann, Uta (2017). "Campaigning in the fourth age of political communication. A multi-method study on the use of Facebook by German and Austrian parties in the 2013 national election campaigns". Information, communication \& society, v. 20, n. 11, pp. 1698-1719.

https://doi.org/10.1080/1369118X.2016.1254269

Manovich, Lev (2001). The language of new media. Cambridge: The MIT Press. ISBN: 9780262133746

Mayer-Schönberger, Viktor; Cukier, Kenneth (2013). Big data: la revolución de los datos masivos. Madrid: Turner. ISBN: 9788415832102

Meso-Ayerdi, Koldo; Mendiguren-Galdospín, Terese; Pérez-Dasilva, Jesús (2017). “Memes políticos difundidos por usuarios de Twitter. Análisis de la jornada electoral del 26J de 2016". El profesional de la información, v. 26, n. 4, pp. 672-683.

https://doi.org/10.3145/epi.2017.jul.11

Miquel-Segarra, Susana; Alonso-Muñoz, Laura; Marcos-García, Silvia (2017). "Buscando la interacción. Partidos y candidatos en Twitter durante las elecciones generales de 2015". Prisma social, v. 18, pp. 34-54.

http://revistaprismasocial.es/article/view/1353

Nahon, Karine (2016). "Where there is social media there is politics". In: Bruns, Axel; Enli, Gunn; Skogerbö, E.; Larsson, Anders; Christensen, Christian (eds.). Routledge companion to social media and politics. New York: Routledge, p. 39-55. ISBN: $978113886076 \mathrm{X}$

Newman, Nic; Fletcher, Richard; Kalogeropoulos, Antonis; Levy, David A. L.; Nielsen, Rasmus-Klein (2018). Reuters Institute digital news report 2018. Oxford: Reuters Institute for the Study of Journalism, University of Oxford.

http://www.digitalnewsreport.org

http://media.digitalnewsreport.org/wp-content/ uploads/2018/06/digital-news-report-2018.pdf

Papacharissi, Zizi (2015). Affective publics: Sentiment, technology, and politics. Oxford: Oxford University Press. ISBN: 9780199999743

Sampedro, Víctor; Martínez-Avidad, Mayra (2018). "The digital public sphere: An alternative and counterhegemonic space? The case of Spain". International journal of communication, v. 12, pp. 23-44.

http://ijoc.org/index.php/ijoc/article/view/6943

Selva-Ruiz, David; Caro-Castaño, Lidia (2017). “Uso de Instagram como medio de comunicación política por parte de los diputados españoles: la estrategia de humanización en la "vieja" y la "nueva" política". El profesional de la información, v. 26, n. 5, pp. 903-915.

https://doi.org/10.3145/epi.2017.sep.12

Solito, Laura; Sorrentino, Carlo (2018). "Political communication and social change. Political communication and challenges in the digital age". Icono 14, v. 16, n. 1, pp. 22-41. https://doi.org/10.71957ri14.v16i1.1161

Stier, Sebastian; Bleier, Arnim; Lietz, Haiko; Strohmaier, Markus (2018). "Election campaigning on social media: Politicians, audiences, and the mediation of political communication on Facebook and Twitter". Political communication, v. 35 , n. 1 , pp. 50-74.

https://doi.org/10.1080/10584609.2017.1334728

Stromer-Galley, Jennifer (2014). Presidential campaigning in the Internet age. New York: Oxford University Press. ISBN: 9780199731947

Sung-Tae, Kim; Young-hwan, Lee (2007). "New functions of Internet mediated agenda-setting: Agenda-rippling and reversed agenda-setting". Korea journalism review, v. 1, n. 2, pp. 3-29.

Sunstein, Cass R. (2009). Republic.com 2.0. Princeton: Princeton University Press. ISBN: 9780691143286

Toff, Benjamin; Nielsen, Rasmus-Klein (2018). "'I just Google it': Folk theories of distributed discovery". Journal of communication, v. 68, n. 3, pp. 636-657.

https://doi.org/10.1093/joc/jqy009

Van-Aelst, Peter; Strömbäck, Jesper; Aalberg, Toril; Esser, Frank; De-Vreese, Claes; Matthes, Jörg; Hopmann, David; Salgado, Susana; Hubé, Nicolas; Stępińska, Agnieszka; Papathanassopoulos, Stylianos; Berganza, Rosa; Legnante, Guido; Reinemann, Carsten; Sheafer, Tamir; Stanyer, James (2017). "Political communication in a high-choice media environment: a challenge for democracy?". Annals of the In- 
ternational Communication Association, v. 41, n. 1, pp. 3-27. https://doi.org/10.1080/23808985.2017.1288551

Van-Dijck, José (2009). "Users like you? Theorizing agency in user-generated content". Media, culture \& society, v. 31, n. 1, pp. 41-58.

https://doi.org/10.1177/0163443708098245

Van-Dijck, José (2013). The culture of connectivity: A critical history of social media. Oxford: Oxford University Press. ISBN: 9780199970780

Van-Dijck, José; Poell, Thomas (2013). “Understanding social media logic". Media and communication, v. 1, n. 1, pp. 2-14. http://dx.doi.org/10.17645/mac.v1i1.70

Ward, Ken (2018). "Social networks, the 2016 US presidential election, and Katian ethics: Applying the categorical imperative to Cambridge Analytica's behavioral microtargeting". Journal of media ethics, v. 33, n. 3, pp. 133-148. https://doi.org/10.1080/23736992.2018.1477047

Weller, Katrin; Bruns, Axel; Burgess, Jean; Mahrt, Merja; Puschmann, Cornelius (2014). Twitter and society. New York: Peter Lang. ISBN: 9781433121708

Wolton, Dominique (2005). Elogio del gran público. BarceIona: Gedisa. 2a ed. ISBN: 9788474324365

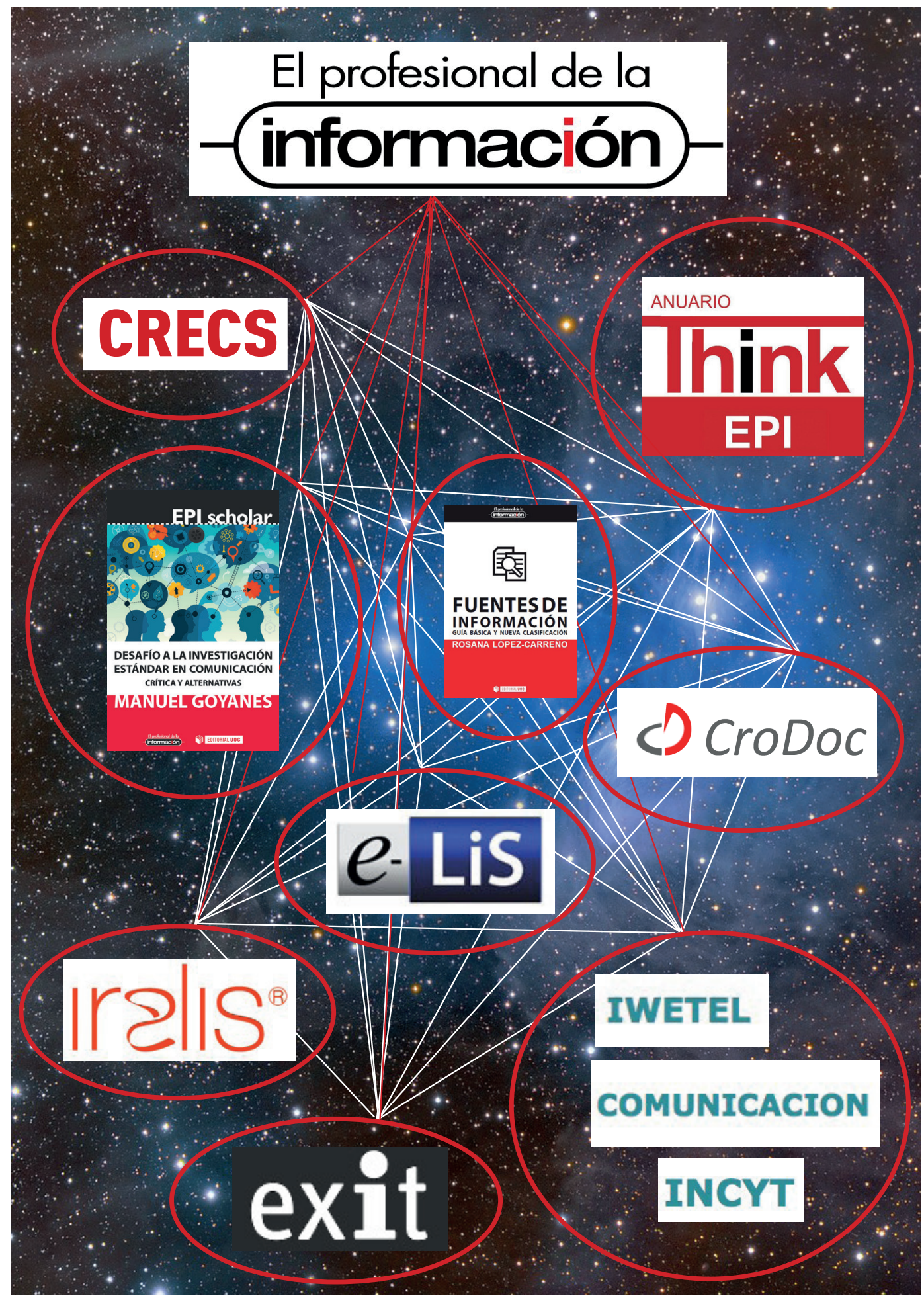

